\title{
Is FDI Spillover Conditioned on Financial Development and Trade Liberalization: Evidence from UMCs
}

\author{
Mahya Nobakht*, Seyedashkan Madani \\ Department of International Business, Nanjing University of Aeronautics and Astronautics \\ *Corresponding author: mahya.nobakht@yahoo.com \\ Received March 01, 2014; Revised April 08, 2014; Accepted April 14, 2014
}

\begin{abstract}
Developing countries take Foreign Direct Investment (FDI) as leverage for economic growth and development as a result of FDI technology spillovers. However, the effect of FDI inflows on economic growth of host countries is conditional on the abilities of those countries in absorbing and accumulating external knowledge. The related literature paid particular attention to the role of the financial system and trade liberalization of recipients. Thus, this paper investigated empirically the intermediary roles of the financial system and trade liberalization as Absorptive Capacity (AC) factors on the FDI led growth nexus. This study provided data evidence from 33 UpperMiddle-income Countries (UMCs) over the period of 1990-2011 to contribute to the existing literature. This empirical study employed the dynamic panel "difference" GMM estimator proposed by Arellano and Bond (1991); since it prevents the biases inherent to economic growth models including auto-correlation, unobserved heterogeneity, and endogeneity between explanatory variables. The results indicated the development of the domestic financial system facilitated FDI technology spillovers in order to enhance the economic growth of UMCs. However, the empirical findings also showed a negative effect of trade openness on stimulating the FDI spillovers.
\end{abstract}

Keywords: FDI inflows spillover, economic growth, financial system, trade liberalization, UMCs

Cite This Article: Mahya Nobakht, and Seyedashkan Madani, "Is FDI Spillover Conditioned on Financial Development and Trade Liberalization: Evidence from UMCs." Journal of Business and Management Sciences, vol. 2, no. 2 (2014): 26-34. doi: 10.12691/jbms-2-2-1.

\section{Introduction}

Among all manifestations of modernity and globalization, Multinational Enterprises (MNEs) and FDI inflows are the primary drivers of international trade and knowledge across borders [1]. Therefore, it is no surprise that a vast literature exists encompassing the different dimensions of FDI flows including debates about the consequences of foreign firm presence and operations in host economies. Although it is expected that the contribution of FDI inflows to economic growth of recipients occurs via different channels such as efficient financial capital and creation of millions of jobs [2], the most important effects of FDI inflows on host countries come from technology spillovers $[3,4,5]$; [Since] $\mathrm{MNCs}^{1}$ are among the most technologically advanced firms, accounting for a substantial part of the world's R\&D investment [6]. Thus, FDI inflows by MNCs and/or MNEs provide a major conduit for accessing international advanced technology, by host economies especially developing ones, at a substantially reduced cost $[7,8]$. This attitude has led developing countries to increasingly regard FDI as a contribution to their development strategies $[3,9,10]$.

${ }^{1}$ Multinational Corporations
FDI into developing countries has sharply increased since the 1990s part because of governments of those countries provide a welcoming climate for investment $[3,10]$ and the growing integration of markets and financial institutions, economic liberalization development, and rapid innovation in financial instruments and technologies [11]. The volume of net FDI inflows into developing countries at the end of the 90's was 7.16 and 17.76 times higher than at the beginning of the 80's and early 90 's ${ }^{2}$. This upward trend continued during the next decade, so that net FDI inflows reached US \$654.72 billion in 2011 which was 75.86 times higher than its volume in 1980 [12].

Although FDI inflows are taken as leverage of economic growth and development by developing countries, FDI technology spillovers realization is conditional on the ability of the host country in absorbing and accumulating the external knowledge and technologies conveyed by the FDI inflows $[1,13,14,15,16]$. These abilities are named national Absorptive Capacity (AC) factors in the literature at the macro level and lead to more Total Factor Productivity (TFP) in the FDI recipients [3,6,17,18,19]. Among the main national AC factors, financial system development $[17,20]$ and trade liberalization development [21,22] are considered as the most important facilitators of technology spillovers

\footnotetext{
${ }^{2}$ Source: calculated by the authors based on UNCTAD 2013, Foreign Direct Investment (current US\$) Online database.
} 
occurrence $[23,24]$. Based on this, the aim of this paper is the empirical investigation of the intermediary role of both financial system and trade liberalization development, separately and together, on the FDI led growth nexus of UMCs over the period of 1990-2011.

The main reason behind selecting UMCs as the case study is that they have received less attention and investigation in the related literature. Based on the knowledge of the authors, this is the first time these effects are considered for UMCs. Furthermore, UMCs are considered among developing countries and much of the influx of FDI toward developing countries has been slanting to them. The average of net FDI inflows of UMCs over the period of 1990-2011 was 4.79 and 39.57 times higher than Lower-Middle-income Countries (LMCs) and Low-Income Countries (LICs), respectively ${ }^{3}$. UMCs' average share of net FDI inflows toward developing countries over the same period was $81.04 \%$, which is quite remarkable ${ }^{4}$. Moreover, all UMC countries are not at the same level of development ${ }^{5}$ which negates the biases resulting from the homogeneity of the variables in the sample. This study has selected 33 UMCs based on the availability of data and their population in 2011(See Table $1 \mathrm{~A}$ in the Appendix). Countries with a population under one million in 2011 have been omitted [25]. China is also dropped, since it is an outlier regarding its FDI absorption and economic growth. The study period of 1990-2011 was chosen because of the popularity of FDI inflows among developing countries as leverage for economic development. This practice was initiated mainly during the 1990s and has continued into the present. The availability of data was also crucial in this selection.

This paper proceeds as follows: the mechanism of financial development and trade liberalization, as national AC factors, are explained in more detail in section two. Then in section three the empirical model and methodology used by this study are expounded. Section four describes the data. Section five presents and analyzes the outcome of the empirical investigation. And finally, the last section provides the conclusion.

\section{Literature Review}

\subsection{Financial System}

The importance of financial intermediaries and markets development for developing countries has been highlighted in the FDI led growth nexus literature $[17,24,26,27]$. Since, it is expected that external knowledge and technology absorption and accumulation are facilitated more efficiently in the presence of a developed financial System [28,29,30].

Financial system development of the host countries can contribute to FDI technology spillovers via the presence and interconnection of local and foreign firms. It can occur through reducing the cost of acquiring information about firms, investment and conducting transaction cost [26,28]; evaluating and monitoring investment projects more effectively and ensuring the highest return on the

\footnotetext{
${ }^{3}$ Source: calculated by the authors based on UNCTAD 2013, Foreign Direct Investment (current US\$) Online database

${ }^{4}$ Source: base on the WDI online data base 2013, and calculated by the authors.

5“How We Classify Countries” World Bank( 2013)
}

capital allocations [20,28,30]; and providing and maintaining more efficient means of financial exchange which encourages a higher volume of efficient domestic and international investments [28,30].

In the main, an effective financial system, reduces the risk related to upgrading the existing or adopting new technologies [20,30]; and permits a "larger pool of savings" to be channeled through their highest value usage and productive investment [28,31]. Moreover, efficiently developed financial instruments and services support local firms in that FDI inflows bring capital-intensive or highly advanced technological plants. This takes place via backward or forward linkages which allow existing firms, as the suppliers, to achieve economies of scale and encourage the creation of new local firms $[20,26]$. In other words, a developed financial system can prevent the crowd-out phenomenon.

Considering the above theoretical debate, the idea of positive and significant effects of a financial system on economic growth and FDI spillovers enjoys a theoretically rather than empirically consensus. Alfaro et al. [17] implied that physical and human capital accumulation do not seem to be the main channel of benefit from FDI, but countries with well-developed financial markets gain significantly from FDI via TFP improvements. Calderòn and Fuentes [32] found that "financial openness most strongly favors" middle income countries, and their financial system development as an AC factor increases their economic growth rate as well. Hermes and Lensink's [20] empirical investigation showed that 37 among their 67 sample countries developed their financial system and received more positive effects from FDI inflows. Most of those countries are in Latin America and Asia. Chee and Nair [21] indicated that financial system development plays an important complementary role on the FDI led growth nexus of 44 Asia and Oceania countries over 1996-2005. Alfaro et al.'s [26] findings revealed that the interaction between FDI and financial systems has significantly positive effects on growth while the financial market by itself has reversed effects on economic growth for non-stock market variables. Levine et al. [33] suggested "exogenous components of financial intermediary development are positively associated with economic growth." Levine and Zervos [34] found that stock markets and banks provisions can positively predict growth, and capital accumulation.

On the other hand, FitzGerald [35] found financial depth and development are not associated with higher rates of economic growth. Ghimire and Giorgioni's [36] findings showed a negative effect of private credit upon economic growth in annual data. They also emphasized the conditional impact of stock over the selection of proxies, and the method of estimation. Ndikumana [37] implied the "structure of the financial system" has no increasing impact on domestic investment and consequently on economic growth while its development can have a positive effect. Durham [27] couldn't find a significant robust effect of international capital flows and stock market capitalization on growth.

\subsection{Trade Liberalization}

International institutions such as the World Bank, IMF, and OECD have proposed developing countries to adopt 
more open trade policies in order to access to the larger and cheaper advanced technological knowledge and more efficient capital stocks [38]. According to the IMF [39], policies toward foreign trade are among the more important factors promoting economic growth and convergence in developing countries [40].

Considering that FDI inflows are the main technology conveyor, trade liberalization levels of the host countries can be effective via both FDI absorption and stimulating FDI technology spillover [22,23,41,42]. Balasubramanyam et al. [22] empirically found the beneficial effect of FDI on the promotion of economic growth is stronger in countries with Export-Promotion (EP) strategies rather than Import-Substitution (IS) ones. However, it is expected that neutrality toward trade enhances economic growth through the promotion of FDI spillovers if it leads to increased industrialization of host countries [13,43]; otherwise, trade liberalization can resulted in vulnerability of economic growth, exploitation of cheap primary resources, and crowd-out effects.

Based on the literature ${ }^{6}$, the effectively positive role of trade liberalization on economic growth, as a national AC factor, can occur via facilitating cheaper and more advanced technologies and imported capital goods $[22,44,45]$; reducing state-run monopolies which eventuated in better allocation of resources toward more productive and greater value activities under the influence of free market forces [22,46]; and connecting local firms to the global markets in order to stimulating the distribution of their goods (backward linkage) or provide them better and more advanced supplies (forward linkage) $[22,44]$.

Conversely, if trade liberalization does not eventuate in the industrialization of the host countries, FDI technology spillovers will reach a zero amount $[13,43,47]$. In such cases, more trade liberalization turns the host economies into a haven for efficient-seeking FDI. And as the consequence, it leads to low technology plant introduction, or complete MNE enclave activities in high-technology or intensive-capital plants which allows no backward and/or forward linkages between local firms and foreign firms [13]. In such situations, MNEs turn the host country into export platforms ${ }^{7}$ [48].

The empirical literature of trade liberalization impact on economic growth and FDI spillovers also shows mixed results. For instance, while Goldar and Kumari [49] implied that after liberalization, the productivity of Indian industry, has improved; Kokko et al. [50] could not find positive significant effects of trade liberalization on Uruguay firms after 1973. Carkovic and Levine [24] also couldn't find a similar effect for trade liberalization variables entered in all their models. [However,] Trevino and Upadhyaya [52] still found that FDI is more likely to have a positive effect on economic growth in more open economies [3]. Ferreira and Rossi [53], by using industrial level data over the period of 1988-90, also confirmed a large productivity improvement across local Brazilian industries after reduction of trade barriers and adopting more liberal trade policies.

\footnotetext{
${ }^{6}$ Based on the neoclassical model of international trade [45] ${ }^{7}$ Export-platform FDI is typically defined as the establishment of foreign production facilities and allocation of part or all of the output to serve a third country [51].
}

\section{Methodology}

Using a panel data approach in this empirical investigation is encouraged by the literature which suggests that panel data included more information than pure cross-section or time-series data in order to exploit the nature of national AC factor effects over the FDI led growth relation $[4,16,21,54]$. This approach can increase the degrees of freedom, and reduce the problems of multicollinearity and biased estimations such as omitted variables [55,56]. This paper has also used the lagged dependent variable, which leads to a dynamic econometric structure, in order to eliminate the auto-correlation problem in the model [57].

In light of the above explanation and based on the canonical dynamic panel economic growth equation $[58,59]$ and national AC function $[6,18]$, the general model employed by this empirical investigation is as the following:

$$
\begin{gathered}
L y_{i t}=\beta_{1} L y_{i t-1}+\beta_{2} L x_{i t}+\beta_{3} L\left(A C_{i t} * F D I_{i t}\right)+u_{i t} \\
u_{i t}=\mu_{i t}+\eta_{i t}+\vartheta_{i t}
\end{gathered}
$$

Where $\mathrm{Ly}_{\text {it }}$ is the dependent variable measured by the logarithm of GDP growth rate per capita for country i in period t. $L y_{i t-1}$ is the lagged dependent variable. $L x_{i t}$ equals a vector of observations on $\mathrm{K}$ logarithm of the explanatory variables included in models in order to control the other main growth determinants effects. $\mathrm{L}\left(\mathrm{AC}_{\mathrm{it}} * \mathrm{FDI}_{\mathrm{it}}\right)$ is identified as the intermediate role of the $\mathrm{AC}$ factor in the model. $\mathrm{AC}_{\mathrm{it}}$ is considered once as financial system development and once as trade liberalization development for country $i$ at time t. FDI $_{\text {it }}$ is FDI inflows for country $i$ at time t. Finally, $\mu_{\mathrm{t}}+\eta_{\mathrm{i}}+\vartheta_{\mathrm{it}}$ are unobserved heterogeneities among individuals and idiosyncratic error term, respectively.

To estimate the above equation, the "difference" Generalized Method of Moments (difference GMM) estimator proposed by Arellano and Bond [60] is employed; since GMM estimators deal with dynamic regression specifications, control for unobserved countryspecific effects, and account for endogeneity between the explanatory variables $[60,61,62,63]$. Another advantage of difference GMM is the usage of internal instrument variables. To define internal valid instruments, this study follows Roodman's [61] instruction. In this regard, all available lags of endogenous variables in level are included as instruments. Using this method requires the assumption that "the explanatory variables are only weakly exogenous, which means that they can be affected by current and past realizations of the growth rate but must be uncorrelated with future realizations of the error term [62]." Exogenous variables are treated as strictly exogenous; and each can be instrumented by itself. Thus, the first difference of these variables are used as standard instruments as well. This study also applied two-step GMM estimators, because they are robust to heteroskedasticity and also asymptotically efficient.

Applying the procedure to the econometric specification produces the following equation:

$$
\begin{aligned}
& \Delta L y_{i t}=\beta_{1} \Delta L y_{i t-1}+\beta_{2} \Delta L x_{i t} \\
& +\beta_{3} \Delta L\left(A C_{i t} * F D I_{i t}\right)+\Delta u_{i t}
\end{aligned}
$$


It must be mentioned that the consistency of ArellanoBond GMM estimation should be checked for the instruments validity and second-order serial correlation of error term via the Sargan test and Arellano and Bond (AB) test, respectively.

Another important issue, before performing difference GMM estimation, is the existence of unit root in the time dimension of variables [64]. Since non-stationary variables can lead to biased estimation and spurious regressions. This study employed Levin, Lin and Chu [65] (LLC); Im, Pesaran and Shin [66] (IPS); Fisher-type test using Augmented Dickey-Fuller (ADF-Fisher); and Fisher-type test using Philips-Perron (PP-Fisher) [67,68]; as the most widely used panel unit root tests, in order to test stationary of its variables.

\section{Data Description}

The data were obtained from UNCTAD statistic database (2013) and World Development Indicators (WDI), World Bank (2013). The dependent variable is measured by the logarithm ${ }^{8}$ of GDP growth rate per capita in order to control inflation terms and economies size of the countries in the sample and obtain more pure estimations.

This study is interested in estimating the effects of two interactive variables, financial AC and trade liberalization AC factors, on the economic growth of UMCs. The former is measured by the Logarithm of multiplication between annual net FDI inflows ratio to GDP and ratio of liquid liabilities to GDP, following the example of the literature [20,21,26,27]. The latter is measured by the Logarithm of multiplication between annual net FDI inflows ratio to GDP and the volume of trade, following the example of the literature [45,69,70].

The other variables considered consist of domestic investment (the logarithm of percentage of annual gross capital formation to GDP); FDI stock in the host economy (the logarithm of percentage of annual growth rate of FDI stock ratio to GDP); quantity of labor force (the logarithm of percentage of population annual growth rate); FDI inflows (the logarithm of annual net FDI inflows ratio to GDP); financial system development (the logarithm of ratio of liquid liabilities to GDP); and trade liberalization(the logarithm of percentage of annual total trade ratio to GDP). The expected signs, based on the described theories, and source of data for the variables are explained at Table 2A and Table 3A in the appendix. The descriptive statistics and correlation matrix of the variables are also reported in Table $4 \mathrm{~A}$ and Table 5A, respectively, in the Appendix.

\section{Empirical Results}

In this section, the estimation results of unit root tests and difference GMM are presented and analyzed. The

\footnotetext{
${ }^{8}$ To take logarithms from both dependent and independent variables, at the first it needs to transform some of variables which have negative values for some observations. In this regard this Paper follows Busse and Hefeker [71] transformation method described in the following as it can save the sign of variables in the model even after taking

logarithm: $y=\ln \left(x+\sqrt{\left(x^{2}+1\right)}\right)$
}

results of unit root tests showed all the variables were stationary at level except labor force (LPOPr) (refer to Table 6A and Table 7A in the appendix); thus the tests were repeated for all variables at first difference.

Table 1. Panel Unit Root Tests Results at first difference

\begin{tabular}{|c|c|c|c|c|}
\hline \multirow[t]{2}{*}{ Variables } & \multicolumn{4}{|c|}{ Intercept } \\
\hline & LLC & IPS & AD-Fisher & PP-Fisher \\
\hline LGDPr & $-25.64^{* * *}$ & $-24.25^{* * *}$ & $543.40^{* * *}$ & $1642.17^{* * *}$ \\
\hline LFDIi & $-24.98^{* * *}$ & $-22.29^{* * *}$ & $498.47^{* * *}$ & $871.82^{* * *}$ \\
\hline LDOMI & $-21.48^{* * *}$ & $-20.63^{* * *}$ & $456.89^{* * *}$ & $683.95^{* * *}$ \\
\hline LFDIs & $-25.10^{* * *}$ & $-26.17^{* * *}$ & $594.50^{* * *}$ & $3157.62^{* * *}$ \\
\hline LPOPr & $-7.41^{* * *}$ & $-15.58^{* * *}$ & $388.77^{* * *}$ & $305.61^{* * *}$ \\
\hline LFD & $-17.59^{* * *}$ & $-16.53^{* * *}$ & $365.05^{* * *}$ & $440.03^{* * *}$ \\
\hline LFDe & $-27.94^{* * *}$ & $-26.84^{* * *}$ & $772.30^{* * * *}$ & $1717.77^{* * *}$ \\
\hline $\begin{array}{r}* * * \text { Sig } \\
\text { rejection } 0\end{array}$ & ant at $1 \%$ & $\begin{array}{r}\text { significan } \\
\text { sis denotes } \\
\text { unit roo }\end{array}$ & $\begin{array}{l}\% \text {, *signifi } \\
\text { panel series }\end{array}$ & $\begin{array}{l}\text { at } 10 \% \text { - } \\
\text { s not have a }\end{array}$ \\
\hline
\end{tabular}

Table 2. Panel Unit Root Tests Results at first difference

\begin{tabular}{|c|c|c|c|c|}
\hline \multirow[t]{2}{*}{ Variables } & \multicolumn{4}{|c|}{ Intercept and Trend } \\
\hline & LLC & IPS & AD-Fisher & PP-Fisher \\
\hline LGDPr & $-22.33^{* * *}$ & $-21.42^{* * *}$ & $432.85^{* * *}$ & $1585.08^{* * *}$ \\
\hline LFDIi & $-21.42^{* * *}$ & $-20.52^{* * *}$ & $409.83^{* * *}$ & $930.942^{* * *}$ \\
\hline LDOMI & $-16.17^{* * *}$ & $-16.54^{* * *}$ & $336.18^{* * *}$ & $585.277^{* * *}$ \\
\hline LFDIs & $-20.91^{* * *}$ & $-21.94^{* * *}$ & $475.13^{* * *}$ & $2475.97^{* * *}$ \\
\hline LPOPr & $-12.17^{* * *}$ & $-18.88^{* * *}$ & $417.07^{* * *}$ & $366.006^{* * *}$ \\
\hline LFD & $-14.18^{* * *}$ & $-14.29^{* * *}$ & $293.48^{* * *}$ & $411.892^{* * *}$ \\
\hline LFDe & $-21.65^{* * *}$ & $-23.00^{* * *}$ & $435.93^{* * *}$ & $1457.29^{* * *}$ \\
\hline \multicolumn{5}{|c|}{$\begin{array}{l}* * * \text { Significant at } 1 \%,{ }^{* *} \text { significant at } 5 \%,{ }^{*} \text { significant at } 10 \%- \\
\text { rejection of the null hypothesis denotes the panel series does not have a } \\
\text { unit root. }\end{array}$} \\
\hline
\end{tabular}

As it is obvious from the Table 1 and Table 2, all of the variables are stationary at $1 \%$ significance, which is common among economic variables. Since this study's empirical regressions are going to be run based on the difference GMM estimator, for variables being stationary at first difference will be enough to involving them in the GMM estimation without further investigation on the cointegration test. Then, the empirical results of the intermediary roles of host economies' financial system and trade liberalization development on the FDI led growth nexus are reported Table 3, Table 4 and Table 5.

In Table 3, there are three specifications consisting of one baseline model and two models which study the direct and interactive effects of the financial system, respectively, on economic growth; then, in Table 4 two models investigated the direct and interactive effects of trade liberalization as well; and the two last models, in Table 5, explored the direct and interactive effects of those variables together. The details and results of these models are presented as the follows. 
Table 3. Effects of financial system on the FDI led growth nexus

\begin{tabular}{|c|c|c|c|}
\hline \multicolumn{4}{|c|}{ Arellano and Bond (1991) difference GMM } \\
\hline & Spec.1 & Spec.2 & Spec.3 \\
\hline LGDPr(-1) & $\begin{array}{l}0.266^{* * *} \\
(0.0000)\end{array}$ & $\begin{array}{l}0.179^{* * *} \\
(0.0000)\end{array}$ & $\begin{array}{l}0.210^{* * *} \\
(0.0000)\end{array}$ \\
\hline LDOMI & $\begin{array}{l}2.291^{* * *} \\
(0.0000)\end{array}$ & $\begin{array}{l}3.807^{* * *} \\
(0.0000)\end{array}$ & $\begin{array}{l}2.587^{* * *} \\
(0.0000)\end{array}$ \\
\hline LFDIs & $\begin{array}{c}0.083^{*} \\
(0.0515)\end{array}$ & $\begin{array}{c}0.043 \\
(0.3978)\end{array}$ & $\begin{array}{c}-0.001 \\
(0.9752)\end{array}$ \\
\hline LPOPr & $\begin{array}{l}-2.418^{* * *} \\
(0.0000)\end{array}$ & $\begin{array}{l}-3.916^{* * *} \\
(0.0000) \\
\end{array}$ & $\begin{array}{l}-2.122^{* * *} \\
(0.0011)\end{array}$ \\
\hline LFDIi & $\begin{array}{l}0.418^{* * *} \\
(0.0002) \\
\end{array}$ & $\begin{array}{l}-0.0381 \\
(0.772) \\
\end{array}$ & $\begin{array}{c}-0.101 \\
(0.4739) \\
\end{array}$ \\
\hline LFD & & $\begin{array}{l}-2.204^{* * *} \\
(0.0000)\end{array}$ & $\begin{array}{c}-0.408 \\
(0.2554)\end{array}$ \\
\hline LFDe & & & $\begin{array}{l}0.0821^{* *} \\
(0.0157) \\
\end{array}$ \\
\hline Number of countries & 33 & 33 & 33 \\
\hline Number of obs. & 623 & 618 & 618 \\
\hline Instrument Rank ${ }^{a}$ & 33 & 33 & 33 \\
\hline Sargan chi-square ${ }^{b}$ & 28.9348 & 27.0174 & 30.5622 \\
\hline$A B$ test $(p-v a l u e)^{c}$ & 0.9077 & 0.2924 & 0.1744 \\
\hline $\begin{array}{l}\text { Note: There are p-value } \\
{ }^{\mathrm{a}} \text { Instrument Rank eq } \\
\text { } \\
\text { 'Under the null hypothe } \\
\text { 'the null hypothesis is } \\
\text { exhibit n }\end{array}$ & $\begin{array}{l}\text { ractices: }{ }^{* x} \\
\text { the numbe } \\
\text { estimation } \\
\text { e instrumen } \\
\text { the residual } \\
\text { he errors in } \\
\text { ond order s }\end{array}$ & $\begin{array}{l}0.01 ;{ }^{* *} \mathrm{p} \\
\text { instrument } \\
\text { sed are not } \\
\text { first differe } \\
\text { correlation }\end{array}$ & $\begin{array}{l}{ }^{*} \mathrm{p}<0.10 \\
\mathrm{~d} \text { in the } \\
\text { egression }\end{array}$ \\
\hline
\end{tabular}

Specification (Spec.) 1 presents the baseline model which consists of the control variables found in the recent and prominent literature. Those variables are the logarithm of domestic investment (LDOMI), population growth (LPOPr), FDI stock growth (LFDIs), Lagged of dependent variable (LGDPr (-1)), and FDI inflows (LFDIi). The result of Spec.1 revealed that all variables have the predicted signs and significantly affect economic growth based on the theories. The lag of GDP growth rate per capita period (LGDPr (-1)) had a positive effect on the current growth rate at $1 \%$ significance. “...The speed of convergence is either low or zero across the countries in the sample [72]". Domestic investment (LDOMI) also showed a positive effect at $1 \%$ significance on the economic growth which is exactly consistence with new growth models such as Barro and Sala-I-Martin [60].They presented that there is a positive relationship between economic growth and capital accumulation over time. Population annual growth rate (LPOPr) indicated a significant and negative impact on the growth rate per capita at $1 \%$. This result is in line with the "population as the economic burden" idea which believes a higher rate of population growth lowers the steady-state level of capital and output per worker and tends thereby to reduce the per capita growth rate for a given initial level of per capita output [60]. Growth rate of FDI stock (LFDIs) affected growth rate per capita positively at $10 \%$. According to the theories the effect of efficient foreign capital accumulation improves the growth rate of host countries [73]. It is also noticeable that FDI inflows (LFDIi) have a positive effect at $1 \%$ significance on the GDP growth rate per capita without controlling the AC factors effects in the model.
One percentage increase in the FDI inflows improves growth rate per capita of the host country $0.41 \%$ at the baseline model.

Spec. 2 indicates the re-estimation of variables after the entry of the financial system (LFD), as a growth determinant, in the equation. The results demonstrated LFD impact on growth is negative and significant at $1 \%$. This result is in line with the findings of Ghimire and Giorgioni [36] and Alfaro et al. [26] that state the nonstock market variables signs are always negative in growth regressions. In this study, Liquid Liabilities ratio to GDP, which is a non-sock variable and a typical measure of financial depth, has been employed as the proxy of the financial system $[20,26,27,33,62]$. The entrance of LFD in the model also affected other variables in the RHS of the equation. LFDIi is not significant any more. As Hermes and Lensink [20] state, it can be interpreted as a confirmation of the conditionally enhancing effect of FDI on the additional requirements. The entrance of LFDI also noticeably improves the positive effect of domestic investment on growth. This result is approved by the literature, such as Ndikumana's [37] findings that financial development is positively related to domestic investment. "LFDIs" is another variable which also showed different behavior. It no longer demonstrated an effect on economic growth. The reason may be that the LFD, in this study, is a non-stock variable and supports sources toward capital flows rather than stocks such as FDI stocks. The negative effect of LPOPr and positive effect of LGDPr (-1) also increased in agreement with the theories.

In Spec. 3, the interaction term (LFDe) has been introduced in the model in order to study whether domestic financial development supports economic growth through FDI technology spillover. LFD and LFDIi were kept in the model, to capturing the effects that do not depend on the national AC variable. The result showed the effect of LFDe was positive and significant at 5\%. It is completely in compliance with the theories explained previously. The entrance of LFDe into Spec. 3 didn't affect the other variables' impact on growth, except LFD which no longer showed any effect on economic growth. This may indicate that development of the domestic financial system, alone without international financial capital, has no effect on UMCs' economic growth. LFDIi and LFDIs remained ineffective as shown by the evidence on their conditional effects on economic growth. The coefficient signs of LGDPr (-1), LDOMI, and LPOPr were still significantly positive, positive and negative, respectively, and in accordance with the theories. It is also noticeable that the effect of LDOMI decreases, but it is still much more than LFDe. This may imply the importance of domestic capital accumulation in enhancing economic growth.

The next model, in Table 4, shows the study of the entry of trade liberalization (LOPEN) in the growth equation. The result of Spec. 4 revealed trade liberalization had a positive direct effect of $1 \%$ significance on UMCs' economic growth. It is in line with the point of view which indicates that international integration can be beneficial for economic growth. All the control variables are significant except FDIs and POPr, while their signs have not changed when compared with the baseline model. 
Table 4. Effects of Trade Liberalization on the FDI led growth nexus Arellano and Bond (1991) difference GMM

\begin{tabular}{|c|c|c|}
\hline & Spec. 4 & Spec. 5 \\
\hline LGDPr(-1) & $\begin{array}{l}0.119^{* * *} \\
(0.0002)\end{array}$ & $\begin{array}{l}0.193^{* * *} \\
(0.0000)\end{array}$ \\
\hline LDOMI & $\begin{array}{l}2.924^{* 2 *} \\
(0.0000)\end{array}$ & $\begin{array}{l}1.202^{* * * *} \\
(0.0000)\end{array}$ \\
\hline LFDIs & $\begin{array}{c}0.122 \\
(0.1396)\end{array}$ & $\begin{array}{c}0.097^{*} \\
(0.0797)\end{array}$ \\
\hline LPOPr & $\begin{array}{l}-0.6510 \\
(0.399)\end{array}$ & $\begin{array}{c}-0.163 \\
(0.7474)\end{array}$ \\
\hline LFDIi & $\begin{array}{l}0.3047^{* *} \\
(0.0172)\end{array}$ & $\begin{array}{c}0.1593 \\
(0.4953)\end{array}$ \\
\hline LOPEN & $\begin{array}{l}6.6827^{* * * *} \\
(0.0000)\end{array}$ & $\begin{array}{l}5.7586^{* * *} \\
(0.0000)\end{array}$ \\
\hline LOPENe & & $\begin{array}{l}-0.0925^{*} \\
(0.0713)\end{array}$ \\
\hline Number of countries & 33 & 33 \\
\hline Number of observations & 620 & 620 \\
\hline Instrument Rank $^{\mathrm{a}}$ & 33 & 33 \\
\hline Sargan chi-square $^{b}$ & 27.6136 & 29.81241 \\
\hline $\mathrm{AB}$ test $(\mathrm{p}-\mathrm{v} \text { alue })^{\mathrm{c}}$ & 0.73730 & 0.930000 \\
\hline $\begin{array}{l}\text { Note: There are p-values in pr } \\
{ }^{\mathrm{a}} \text { Instrument Rank equals to } \\
\text { bunder the null hypothesis the } \\
\text { 'the null hypothesis is that th } \\
\text { exhibit no seco }\end{array}$ & $\begin{array}{l}{ }^{*} \mathrm{P}<0.01 ; \\
\mathrm{r} \text { of instrun } \\
\text { ts used are } \\
\text { the first dif } \\
\text { rial correla }\end{array}$ & $\begin{array}{l}5 ;{ }^{*} \mathrm{p}<0.10 . \\
\text { sed in the } \\
\text { related with } \\
\text { regression }\end{array}$ \\
\hline
\end{tabular}

In order to investigate the intermediary effect of trade liberalization (LOPENe) on the FDI led growth nexus, LOPENe has also been introduced in Spec. 5 in Table 4; while LOPEN or LFDIi were kept in the model to check whether LOPENe captured their effect in the model. The result indicated LOPENe had a negative effect on the economic growth rate of host countries at $10 \%$ significance. The negative effect of interaction between FDI inflows and trade volume confirms the findings of Shafaeddin [43], Schulz [48], and Alfaro [13] about the hypothesized link between FDI and trade protection termed as export-platform FDI which was explained above. The behavior of the other variables in the model didn't change except for FDIi and FDIs. Keeping their positive signs, FDIi was not any more significant while FDIs became significant. These results indicate the positive effect of FDI stocks on economic growth when controlled for openness. It is noteworthy that although domestic investment was still positive and strongly significance, its effect on economic growth decreased by a large absolute value which may be caused by the crowdout effect especially for local small business.

Table 5 includes Spec. 6 and Spec. 7 which studied the direct and interactive effects of the financial system and trade liberalization with FDI inflows. In Spec. 6 both LFD and LOPEN were investigated in a model together. Their signs didn't change and are in accordance with Spec. 2 and 4; meanwhile LFD at 5\% and LOPEN at $1 \%$ are significant. The result is completely in line with previous theories and investigations. Other variables in the model such as LGDPr and LDOMI kept their strong and positive significance effects on economic growth, while LFDIs, LFDIi and LPOPr showed no effects. For estimation of both national AC factors in one model, they have been included in Spec. 7, keeping all variables of Spec. 6 in the model. They (LFDe and LOPENe) were significant and followed their signs at Spec. 3 and 5. LOPENe was negative and LFDe was positive at 5\%. Control variables such as LGDPr (-1), LDOMI and LFDIs were positively significant, while LFDIi was negative and significant at
5\%. LPOPr still showed no effect. The significance and positive impacts of LGDPr (-1), LDOMI in all seven specifications imply their important role on the economic growth of UMC countries.

Table 5. Effects of financial system and Trade Liberalization on the FDI led growth nexus

\begin{tabular}{|c|c|c|}
\hline \multicolumn{3}{|c|}{ Arellano and Bond (1991) difference GMM } \\
\hline & Spec.6 & Spec.7 \\
\hline LGDPr(-1) & $\begin{array}{l}0.116^{* * *} \\
(0.0001)\end{array}$ & $\begin{array}{l}0.107^{* * *} \\
(0.0002)\end{array}$ \\
\hline LDOMI & $\begin{array}{l}3.1831^{* * *} \\
(0.0000)\end{array}$ & $\begin{array}{l}3.618^{* * *} \\
(0.0005)\end{array}$ \\
\hline LFDIs & $\begin{array}{c}0.059 \\
(0.458)\end{array}$ & $\begin{array}{l}0.1326^{*} \\
(0.0542)\end{array}$ \\
\hline LPOPr & $\begin{array}{c}0.370 \\
(0.5511)\end{array}$ & $\begin{array}{c}-0.3244 \\
(0.661)\end{array}$ \\
\hline LFDIi & $\begin{array}{c}-0.184 \\
(0.2278)\end{array}$ & $\begin{array}{c}-0.6569^{* *} \\
(0.0159)\end{array}$ \\
\hline LFD & $\begin{array}{l}-1.349^{* * *} \\
(0.0059)\end{array}$ & $\begin{array}{l}-2.421^{* * *} \\
(0.0053)\end{array}$ \\
\hline LFDe & & $\begin{array}{l}0.9179^{* *} \\
(0.0185)\end{array}$ \\
\hline LOPEN & $\begin{array}{l}5.064^{* * *} \\
(0.0001)\end{array}$ & $\begin{array}{l}5.7093^{* * *} \\
(0.0000)\end{array}$ \\
\hline LOPENe & & $\begin{array}{l}-0.587^{* *} \\
(0.0388)\end{array}$ \\
\hline Number of countries & 33 & 33 \\
\hline Number of observations & 616 & 616 \\
\hline Instrument Rank $^{\mathrm{a}}$ & 33 & 33 \\
\hline Sargan chi-square $^{b}$ & 27.68132 & 28.83363 \\
\hline AB test(p-value $)^{\mathrm{c}}$ & 0.316 & 0.6973 \\
\hline $\begin{array}{l}\text { Note: There are p-values in p } \\
\text { aa Instrument Rank equals to } \\
{ }^{\mathrm{b}} \text { Under the null hypothesis the } \\
\text { the null hypothesis is that th } \\
\text { exhibit no seco }\end{array}$ & $\begin{array}{l}* \mathrm{P}<0.01 ; * \\
\text { of instrun } \\
\text { ts used are } \\
\text { s. } \\
\text { the first dif } \\
\text { erial correla }\end{array}$ & $\begin{array}{l}5 ;{ }^{*}<0.10 \text {. } \\
\text { ed in the } \\
\text { related with } \\
\text { regression }\end{array}$ \\
\hline
\end{tabular}

\section{Conclusion}

The empirical literature on the intermediary role of financial system and trade liberalization development, as national AC factors on FDI led growth nexus, is hardly conclusive. Therefore, this paper attempts to extend previous studies in two respects. First and most important, this paper covered the lack of studying on UMCs. While these countries absorbed most of FDI inflows toward developing countries during 1990-2011, they have received less attention and investigation in the related literature. Based on the knowledge of the authors, this is the first time these effects are considered for UMCs. Second, it also examined whether the impact of these two AC factors were changed when they were developed simultaneously.

Thus, based on endogenous growth theories, this paper has developed seven models including GDP growth rate per capita, as the dependent variable; lagged of GDP growth rate per capita, domestic investment, growth rate of FDI stock, population growth rate, FDI inflows, financial system development and trade liberalization as the control variables; and interaction of FDI inflows with financial system and trade liberalization as the interested explanatory variables. These models were estimated utilizing the two-step difference GMM estimator proposed by Arellano and Bond [60] in order to cope with dynamic structure, country-specific features, and endogeneity between the explanatory variables. It also examined 
whether the unit root exists in the time dimension of panel data, to avoid spurious regressions, by means of several panel unit root tests.

The empirical analyses showed that the development of a UMCs' financial system improves the economic growth of those countries via its role in facilitating FDI technology spillovers. However, the results of this paper revealed a negative effect of trade liberalization on stimulating FDI spillovers. It can be implied that if policy packages are not considered by the policy makers of UMCs in order to avoid the crowd-out effects of FDI or export-platform FDI condition, the more liberal trade policies cannot lead to the positive externalities from FDI. These empirical results clearly confirm that FDI inflows and stocks do not have an independent impact on the longrun economic growth of UMCs.

It also found that UMCs' financial system development without the presence of international financial capital is not effective on their economic growth. Meanwhile, the increase in trade volume of UMCs is significantly positive on their economic growth. The importance of domestic capital accumulation in enhancing UMCs' economic growth is also implied in the empirical results.

Investigating the effect of financial system and trade liberalization simultaneously also revealed that the effect of financial system development on facilitating FDI spillover was improved considerably with a higher level of trade liberalization although trade liberalization, itself, still showed a negative effect.

In sum, these findings suggest UMCs should support their domestic financial system development and entrance of international financial capitals, especially FDI, into their financial markets with an emphasis on the improvement of their domestic investment. It is also necessary to employ effective policies, When UMCs increase their trade liberalization to attract more FDI inflows, in order to improve their local firms' ability of getting more benefit from FDI while also supporting more advanced industrialization process.

\section{Appendix}

Table 1A. Country Sample

Algeria; Latvia; Angola; Lebanon; Argentina; Lithuania; Azerbaijan; Malaysia; Belarus; Mauritius; Botswana; Mexico; Brazil; Namibia; Bulgaria; Panama; Chile; Peru; Colombia; Romania; Costa Rica; Russian Federation; Dominican Republic; South Africa; Ecuador; Thailand; Iran; Tunisia; Jordan; Turkey; Kazakhstan; Uruguay; Venezuela

Source: World Bank list of UMC economies July 2012

Table 2A. List of variables used in the analyses

\begin{tabular}{|c|c|}
\hline Variable & Definition \\
\hline LGDPr & GDP growth rate per capita (Dependent Variable) \\
\hline LFDIi & percentage of annual net FDI inflows ratio to GDP \\
\hline LDOMI & percentage of annual gross capital formation to GDP \\
\hline LFDIs & percentage of annual growth rate of FDI stock ratio to GDP \\
\hline LPOPr & percentage of annual growth rate \\
\hline LFD & percentage of annual liquid liabilities ratio to GDP \\
\hline LFDe & LFD *LFDIi \\
\hline LOPEN & percentage of annual total trade ratio of to GDP \\
\hline LOPENe & LFD *LFDIi \\
\hline
\end{tabular}

Table 3A. List of variables used in the analyses

\begin{tabular}{|c|c|c|}
\hline Variable & Sources & Sign \\
\hline LGDPr & UNCTAD (2013) & ----- \\
\hline LFDIi & UNCTAD (2013) & positive \\
\hline LDOMI & WDI (2013) & positive \\
\hline LFDIs & authors' calculation based on UNCTAD (2013) & positive \\
\hline LPOPr & UNCTAD (2013) & negative \\
\hline LFD & WDI (2013) & positive \\
\hline LFDe & Calculated by authors & positive \\
\hline LOPEN & WDI (2013) & positive \\
\hline LOPENe & Calculated by authors & positive \\
\hline
\end{tabular}

Table 4A. Descriptive Statistics of the Variables Used in the Regressions

\begin{tabular}{|c|c|c|c|c|c|c|}
\hline Variable & Mean & Median & Max. & Min. & Std. Dev. & Ob. \\
\hline LGDPr & 1.305 & 1.9118 & 4.238 & -3.548 & 1.661 & 675 \\
\hline LDOMI & 3.824 & 3.832 & 4.753 & 2.870 & 0.274 & 675 \\
\hline LFDIs & 2.671 & 3.328 & 8.126 & -5.099 & 2.335 & 675 \\
\hline LPOPr & 0.892 & 1.131 & 3.109 & -1.677 & 0.769 & 675 \\
\hline LFDIi & 1.609 & 1.716 & 4.503 & -3.359 & 1.001 & 675 \\
\hline LOPEN & 4.956 & 4.991 & 6.088 & 3.315 & 0.542 & 675 \\
\hline LFD & 4.449 & 4.353 & 6.205 & 2.844 & 0.621 & 675 \\
\hline
\end{tabular}

Table 5A. Correlation matrix of the variables included in specification model

\begin{tabular}{|c|c|c|c|c|c|c|c|}
\hline Variable & 今) & 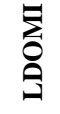 & 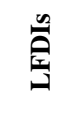 & ڤ్ & 堨 & 贫 & 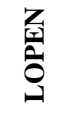 \\
\hline LGDPr & 1.00 & & & & & & \\
\hline LDOMI & 0.26 & 1.00 & & & & & \\
\hline LFDIs & 0.10 & 0.06 & 1.00 & & & & \\
\hline LPOPr & -0.05 & 0.03 & -0.21 & 1.00 & & & \\
\hline LFDIi & 0.17 & 0.15 & 0.28 & $\begin{array}{l}-0.13 \\
\end{array}$ & 1.00 & & \\
\hline LFD & -0.00 & 0.20 & -0.04 & 0.21 & 0.12 & 1.00 & \\
\hline LOPEN & 0.17 & 0.28 & -0.00 & -0.10 & 0.24 & 0.30 & 1.00 \\
\hline
\end{tabular}

Table 6A. Panel Unit Root Tests Results at level

\begin{tabular}{|c|c|c|c|c|}
\hline \multirow[t]{2}{*}{ Variable } & \multicolumn{4}{|c|}{ Intercept } \\
\hline & LLC & IPS & AD-Fisher & PP-Fisher \\
\hline LGDPr & $-11.49^{* * *}$ & $-12.01^{* * * *}$ & $262.8^{* * *}$ & $273.4^{* * *}$ \\
\hline LFDIi & $-6.59^{* * *}$ & $-5.726^{* * *}$ & $141.8^{* * *}$ & $133.7^{* * *}$ \\
\hline LDOMI & $-8.25^{* * *}$ & $-7.588^{* * * *}$ & $180.1^{* * *}$ & $133.5^{* * *}$ \\
\hline LFDIs & $-14.01^{* * * *}$ & $-13.75^{* * * *}$ & $307.7^{* * *}$ & $331.7^{* * *}$ \\
\hline LPOPr & 3.25754 & 1.2577 & $88.38^{* *}$ & 58.659 \\
\hline LFD & $-3.71^{* * * *}$ & $-1.64^{* *}$ & $110.8^{* * *}$ & $126.6^{* * * *}$ \\
\hline LFDe & $-9.25^{* * *}$ & $-6.85^{* * *+1}$ & $176.8^{* * *}$ & $205.2^{* * *}$ \\
\hline LOPEN & $-5.38^{* * *}$ & $-5.97^{* * *}$ & $160.9^{* * * *}$ & $131.3^{* * *}$ \\
\hline LOPENe & $-10.84^{* * * \pi}$ & $-8.372^{* * *+1}$ & $201.7^{* * * *}$ & $184.8^{* * * 2}$ \\
\hline \multicolumn{5}{|c|}{$\begin{array}{l}\text { *** Significant at } 1 \%, * * \text { significant at } 5 \% \text {, *significant at } 10 \% \text { - rejection } \\
\text { of the null hypothesis denotes the panel series does not have a unit root. } \\
\text { the values in front of each variable are t-statistic }\end{array}$} \\
\hline
\end{tabular}

Table 7A. Panel Unit Root Tests Results at level

\begin{tabular}{|c|c|c|c|c|}
\hline Variable & \multicolumn{5}{|c|}{ Intercept and Trend } \\
\hline & LLC & IPS & AD-Fisher & PP-Fisher \\
\hline LGDPr & $-9.94^{* * * *}$ & $-7.65^{* * *}$ & $180.4^{* * * *}$ & $190.3^{* * * *}$ \\
\hline LFDIi & $-6.38^{* * *}$ & $-5.65^{* * *}$ & $147.3^{* * *}$ & $125.8^{* * *}$ \\
\hline LDOMI & $-4.38^{* * *}$ & $-4.52^{* * *}$ & $125.2^{* * *}$ & $128.0^{* * *}$ \\
\hline LFDIs & $-12.09^{* * *}$ & $-11.58^{* * *}$ & $247.4^{* * *}$ & $296.6^{* * *}$ \\
\hline LPOPr & 8.001 & 0.089 & $91.55^{* *}$ & 62.3352 \\
\hline LFD & $-6.6^{* * *}$ & $-2.8^{* * *}$ & $107.4^{* * *}$ & $134.3^{* * *}$ \\
\hline LFDe & $-8.36^{* * * *}$ & $-7.80^{* * * *}$ & $162.4^{* * * *}$ & $199.2^{* * * *}$ \\
\hline LOPEN & $-7.23^{* * * *}$ & $-5.98^{* * *}$ & $150.4^{* * * *}$ & $108.6^{* * *}$ \\
\hline LOPENe & $-8.34^{* * *}$ & $-7.43^{* * *}$ & $166.6^{* * *}$ & $163.7^{* * *}$ \\
\hline
\end{tabular}

*** Significant at $1 \%$, **significant at $5 \%$, *significant at $10 \%$ - rejection of the null hypothesis denotes the panel series does not have a unit root. the values in front of each variable are t-statistic

The maximum lag length selection based on automatic Schwarz Information criterion. 


\section{References}

[1] Jones, G. (2005). Multinationals and global capitalism (p. 277). Oxford: Oxford University Press: pp. 3, 260

[2] World Bank Group. (2010). Investing across Borders 2010: Indicators of foreign direct investment regulation in 87 economies. World Bank Publications.

[3] Adams, S. (2009). Can foreign direct investment (FDI) help to promote growth in Africa. African Journal of Business Management, 3 (5), 178-183.

[4] Johnson, A. (2006). The effects of FDI inflows on host country economic growth. The Royal Institute of technology. Centre of Excellence for studies in Science and Innovation http://www.infra.kth.se/cesis/research/publications/workingpapers.

[5] Blomström, M., \& Kokko, A. (1996). The impact of foreign investment on host countries: a review of the empirical evidence. Policy Research Working Paper, 1745.

[6] Borensztein, E., De Gregorio, J., \& Lee, J. W. (1998). How does foreign direct investment affect economic growth?. Journal of international Economics, 45 (1), 115-135.

[7] Aitken, B., Hanson, G. H., \& Harrison, A. E. (1997). Spillovers, foreign investment, and export behavior. Journal of International economics, 43 (1), 103-132.

[8] Bengoa, M., \& Sanchez-Robles, B. (2003). Foreign direct investment, economic freedom and growth: new evidence from Latin America. European journal of political economy, 19 (3), 529-545.

[9] Imoudu, E. C. (2012). The Impact of Foreign Direct Investment on Nigeria's Economic Growth; 1980-2009: Evidence from the Johansen's Co-integration Approach. International Journal of Business and Social Science, 3 (6), 122-134.

[10] Te Velde, D. W. (2006). Foreign Direct Investment and Development: An Historical Perspective. Background Paper for World Economic and Social Survey for.

[11] Marr, A. (1997). Foreign direct investment flows to low-income countries: a review of the evidence. Overseas Development Institute Briefing Paper. London.

[12] World Bank Group. International Debt Statistics (2013): External Debt of Developing Countries. World Bank-free PDF, 2013.

[13] Alfaro, L. (2003). Foreign direct investment and growth: Does the sector matter. Harvard Business School, 1-31.

[14] Xu, B. (2000). Multinational enterprises, technology diffusion, and host country productivity growth. Journal of Development Economics, 62 (2), 477-493.

[15] Balasubramanyam, V. N., Salisu, M., \& Sapsford, D. (1999). Foreign direct investment as an engine of growth. Journal of International Trade \& Economic Development, 8 (1), 27-40.

[16] De Mello Jr, L. R. (1997). Foreign direct investment in developing countries and growth: A selective survey. The Journal of Development Studies, 34 (1), 1-34.

[17] Alfaro, L., Kalemli-Ozcan, S., \& Sayek, S. (2009). FDI, productivity and financial development. The World Economy, 32 (1), 111-135.

[18] Criscuolo, P., \& Narula, R. (2008). A novel approach to national technological accumulation and absorptive capacity: aggregating Cohen and Levinthal. The European Journal of Development Research, 20 (1), 56-73.

[19] Li, X., \& Liu, X. (2005). Foreign direct investment and economic growth: an increasingly endogenous relationship. World development, 33 (3), 393-407.

[20] Hermes, N., \& Lensink, R. (2003). Foreign direct investment, financial development and economic growth. The Journal of Development Studies, 40 (1), 142-163.

[21] Chee, Y. L., \& Nair, M. (2010). The Impact of FDI and Financial Sector Development on Economic Growth: Empirical Evidence from Asia and Oceania. International Journal of Economics and Finance, 2 (2), P 107.

[22] Balasubramanyam, V. N., Salisu, M., \& Sapsford, D. (1996). Foreign direct investment and growth in EP and IS countries. The Economic Journal, 92-105.

[23] Sukar, A., Ahmed, S., \& Hassan, S. (2011). The Effects of Foreign Direct Investment on Economic Growth: The Case of Subsahara Africa. Southwestern Economic Review, 34, 61-74.

[24] Carkovic, M., \& Levine, R. (2002). Does foreign direct investment accelerate economic growth? U of Minnesota Department of Finance Working Paper.
[25] Schulz, H. (2009). Political Institutions and Foreign Direct Investment in Developing Countries: Does the Sector Matter?. Available at SSRN 1403983.

[26] Alfaro, L., Chanda, A., Kalemli-Ozcan, S., \& Sayek, S. (2003). FDI and Economic Growth: The Role of Local Financial Markets.

[27] Durham, J. B. (2004). Absorptive capacity and the effects of foreign direct investment and equity foreign portfolio investment on economic growth. European economic review, 48 (2), 285-306.

[28] Huang, Y. (2010). Determinants of Financial Development. Palgrave Macmillan.

[29] Levine, R. (1997). Financial development and economic growth: views and agenda. Journal of economic literature, 688-726.

[30] Levine, R. (2005). Finance and growth: theory and evidence. Handbook of economic growth, 1, 865-934.

[31] Jahan, S., \& McDonald, B. (2011). ABigger slice. Finance \& Development, 17.

[32] Calderón, C., \& Fuentes, R. (2006). Complementarities between institutions and openness in economic development: Evidence for a panel of countries. Cuadernos de economía, 43(127), 49-80.

[33] Levine, R., Loayza, N., \& Beck, T. (2000). Financial intermediation and growth: Causality and causes. Journal of monetary Economics, 46 (1), 31-77.

[34] Levine, R., \& Zervos, S. (1996). Stock markets, banks, and economic growth (No. 1690). The World Bank.

[35] FitzGerald, V. (2007). Financial development and economic growth: a critical view. Flat World, Big Gaps, ed. KS Jomo. Hyderabad: Orient Longman. Available at http://www.valpyfitzgerald.com/files/09EVKFfinance.pdf

[36] Ghimire, B., \& Giorgioni, G. (2009). Puzzles in financial development and economic growth. Working Paper, Liverpool Business School, Liverpool John Moores University.

[37] Ndikumana, L. (2000). Financial determinants of domestic investment in Sub-Saharan Africa: Evidence from panel data. World Development, 28 (2), 381-400.

[38] UNCTAD, G. (2012). World investment report: Toward a New Generation of Investment Policies. Unite Nations. New York and Geneva, 2012.

[39] IMF. (1997). World Economic Outlook, Washington. : p. 84

[40] Rodriguez, F., \& Rodrik, D. (2001). Trade policy and economic growth: a skeptic's guide to the cross-national evidence. In NBER Macroeconomics Annual 2000, Volume 15 (pp. 261-338). MIT PRess.

[41] Nicet-Chenaf, D., \& Rougier, E. (2009). FDI and growth: A new look at a still puzzling issue (No. 2009-13). Groupe de Recherche en Economie Théorique et Appliquée.

[42] De Mello Jr, L. R. (1999). Foreign direct investment-led growth: evidence from time series and panel data. Oxford Economic Papers, 51 (1), 133-151.

[43] Shafaeddin, M. S. (2005). Trade liberalization and economic reform in developing countries. The IMF, World Bank and Policy Reform, 155.: pp. 2, 20

[44] Anyanwu, J. C. (2012). Why Does Foreign Direct Investment Go Where It Goes?: New Evidence From African Countries. Annals of Economics and Finance, 13 (2), 425-462.

[45] David, H. L. (2007). A Guide to Measures of Trade Openness and Policy. Retrieved February, 22, 2013.

[46] UNCTAD, G. (2012). World investment report: Toward a New Generation of Investment Policies. Unite Nations. New York and Geneva, 2012.

[47] Calderón, C., Loayza, N., \& Schmidt-Hebbel, K. (2006). External conditions and growth performance. External Vulnerability and Preventive Policies. Central Bank of Chile, Santiago.

[48] Schulz, H. (2009). Political Institutions and Foreign Direct Investment in Developing Countries: Does the Sector Matter?. Available at SSRN 1403983.

[49] Goldar, B., \& Kumari, A. (2003). Import liberalization and productivity growth in Indian manufacturing industries in the 1990s. The Developing Economies, 41 (4), 436-60.

[50] Kokko, A., Zejan, M., \& Tansini, R. (2001). Trade regimes and spillover effects of FDI: Evidence from Uruguay. Weltwirtschaftliches Archiv, 137 (1), 124-149.

[51] Greenaway, D., \& Kneller, R. (2007). Firm heterogeneity, exporting and foreign direct investment. The Economic Journal, 117 (517), F134-F161.

[52] Trevino, L. J., \& Upadhyaya, K. P. (2003). RESEARCH NOTE Foreign aid, FDI and economic growth: evidence from Asian countries. United Nations, 12 (2), 119. 
[53] Ferreira, P. C., \& Rossi, J. L. (2003). New Evidence from Brazil on Trade Liberalization and Productivity Growth*. International Economic Review, 44 (4), 1383-1405.

[54] Lai, M., Peng, S., \& Bao, Q. (2006). Technology spillovers, absorptive capacity and economic growth. China Economic Review, 17 (3), 300-320.

[55] Hsiao, C. (2003). Analysis of panel data (Vol. 34). Cambridge university press.: p. 311

[56] Wooldridge, J. M. (2009). Introductory Econometrics: A Modern Approach: A Modern Approach. Cengage Learning.: p. 10

[57] Nerlove, M. (2000, June). An essay on the history of panel data econometrics. In Proceedings of Ninth International Conference on Panel Data, Geneva, Switzerland.: p. 13

[58] Moral-Benito, E. (2012). Determinants of economic growth: a Bayesian panel data approach. Review of Economics and Statistics, 94 (2), 566-579.

[59] Barro, R. J., \& Sala-i-Martin, X. (2004). Economic Growth: MIT Press. Cambridge, Massachusettes.: pp. 20, 285-316

[60] Arellano, M., \& Bond, S. (1991). Some tests of specification for panel data: Monte Carlo evidence and an application to employment equations. The review of economic studies, 58 (2), 277-297.

[61] Roodman, D. (2009). How to do xtabond2: An introduction to difference and system GMM in Stata. Stata Journal, 9 (1), 86.

[62] Beck, T., Levine, R., \& Loayza, N. (2000). Finance and the Sources of Growth. Journal of financial economics, 58 (1), 261300.

[63] Madani, S., \& Nobakht, M. (2014). Political Regimes and FDI Inflows: Empirical Evidence from Upper Middle Income Countries. Journal of Finance and Economics, 2 (3), 75-82.
[64] Baltagi, Badi. Econometric analysis of panel data. Wiley. com, 2005.: p. 239

[65] Levin, A., Lin, C. F., \& James Chu, C. S. (2002). Unit root tests in panel data: asymptotic and finite-sample properties. Journal of econometrics, 108 (1), 1-24.

[66] Im, K. S., Pesaran, M. H., \& Shin, Y. (2003). Testing for unit roots in heterogeneous panels. Journal of econometrics, 115(1), 53-74.

[67] Maddala, G. S., \& Wu, S. (1999). A comparative study of unit root tests with panel data and a new simple test. Oxford Bulletin of Economics and statistics, 61 (S1), 631-652.

[68] Choi, I. (2001). Unit root tests for panel data. Journal of international money and Finance, 20 (2), 249-272.

[69] Alesina, A., Spolaore, E., \& Wacziarg, R. (2005). Trade, growth and the size of countries. Handbook of economic growth, 1, 14991542.

[70] Michalopoulos, C., \& Ng, F. (2013). Trends in developing country trade 1980-2010. World Bank Policy Research Working Paper, (6334).

[71] Busse, M., \& Hefeker, C. (2007). Political risk, institutions and foreign direct investment. European Journal of Political Economy, 23 (2), 397-415.

[72] Moral-Benito, E. (2010). Panel growth regressions with general predetermined variables: likelihood-based estimation and Bayesian averaging. CEMFI WP No, 1006.

[73] Olofsdotter, K. (1998). Foreign direct investment, country capabilities and economic growth. Review of World Economics, 134 (3), 534-547. 